\title{
SIR JOHN PRINGLE: HOSPITAL REFORMER, MORAL PHILOSOPHER AND PIONEER OF ANTISEPTICS
}

\author{
by \\ SYDNEY SELWYN
}

Scotland has produced at least three medical men who can take their place beside the great Renaissance figures in versatility and breadth of learning. The late seventeenth century was adorned by Sir Robert Sibbald, the eminent physician, historian, geographer and naturalist. In the nineteenth century, Sir James Simpson excelled in a bewildering variety of activities ranging from archaeology to obstetrics. The subject of this paper lived in the intervening century, and was even more remarkable than either Sibbald or Simpson, if this is conceivable. It is certainly noteworthy that although all three men were appointed professors in the University of Edinburgh only Dr. Pringle occupied a chair in the Faculty of Arts.

Biographical material on Pringle is surprisingly scanty. There are two eighteenthcentury accounts of his life. The first, by his close friend Andrew Kippis was published in 1783, and introduces a collected edition of Pringle's Discourses. ${ }^{1}$ Though brief, this is the only authoritative biography available. The other near-contemporary memoir is by Benjamin Hutchinson, ${ }^{2}$ but it is merely a verbatim transcript from Kippis, with omissions. Subsequent biographers and medical historians, with two exceptions, deal perfunctorily with Pringle and add nothing to Kippis's account. Dorothea Singer, however, presents additional material in her valuable paper entitled Sir John Pringle and his Circle. ${ }^{3}$ Several contemporary sources including some of Pringle's correspondence are examined in detail, but the commentary on Pringle himself is somewhat overshadowed by the abundant information on his 'circle'. Moreover, though Pringle's liberality and his influence on contemporaries are freely admitted in the paper, his important achievements have been overlooked in a number of instances. On the other hand, King, in his book on eighteenth-century medicine, ${ }^{4}$ fully recognises the importance of Pringle's work in relation to fevers and antiseptics, but does not attempt a general account. More recently, Pringle's important position in the history of military medicine has been emphasized by Hamilton. ${ }^{5}$

Born in 1707 at Stichill (or 'Stichel') House in Roxburghshire, Pringle, who was the youngest son of a baronet, received his first formal education at the University of St. Andrews. Here he was guided chiefly by a cousin who was the Professor of Greek; and after studying the classics and philosophy for a few years, Pringle, at the age of 20, moved on to Edinburgh to study medicine. He stayed in Edinburgh for only one year, and in $\mathbf{1 7 2 8}$ he hastened to Leyden, apparently to benefit by the teaching of the ageing Boerhaave. However, according to James Boswell-whom Kippis cites-Pringle left Edinburgh with the intention of following a mercantile career, but in Holland he happened to hear a lecture by Boerhaave, and immediately decided to study medicine under that master.

Haller and Van Swieten were amongst his fellow students, but Pringle was not, at that time, greatly impressed by Van Swieten's ability as a physician. During a 


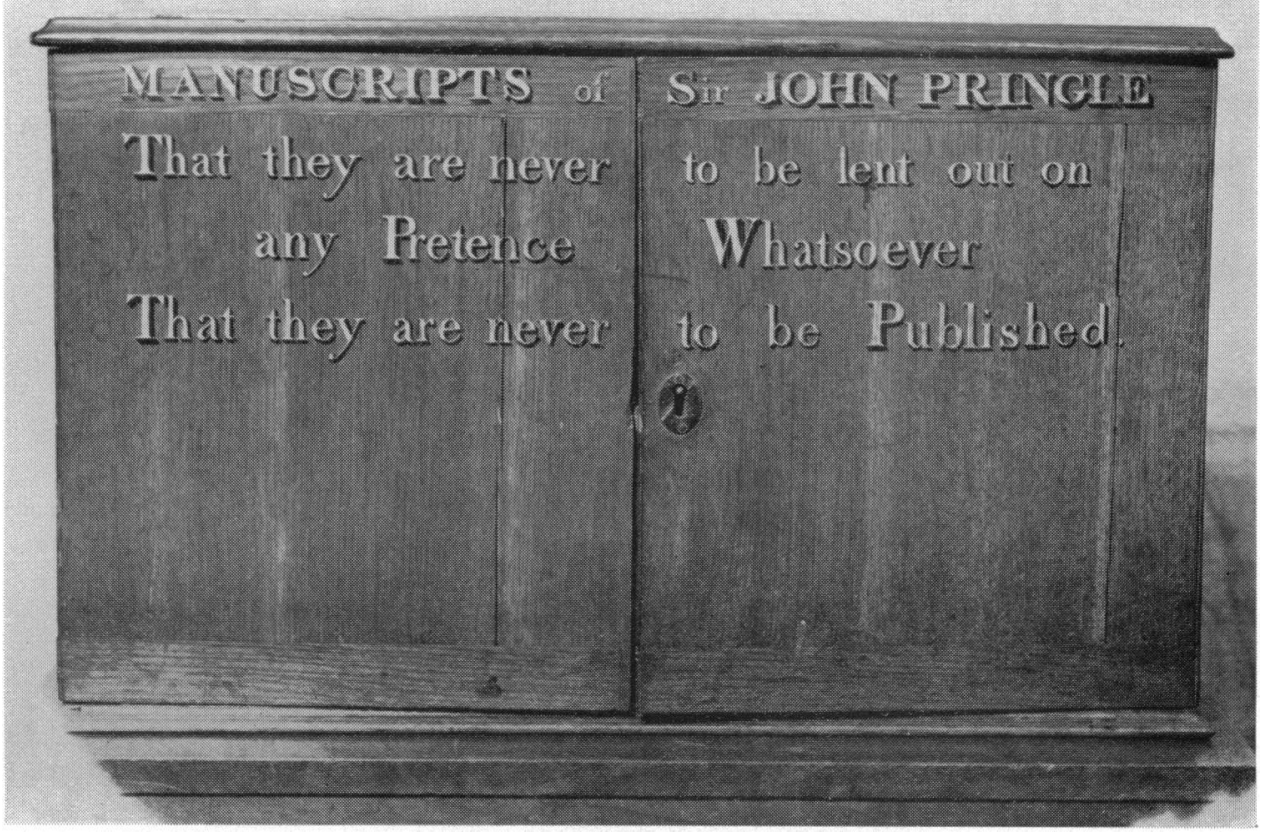

Figure 1

Case containing Pringle's Medical and Physical Observations. (Photograph by courtesy of the Royal College of Physicians, Edinburgh.) (see p. 272)

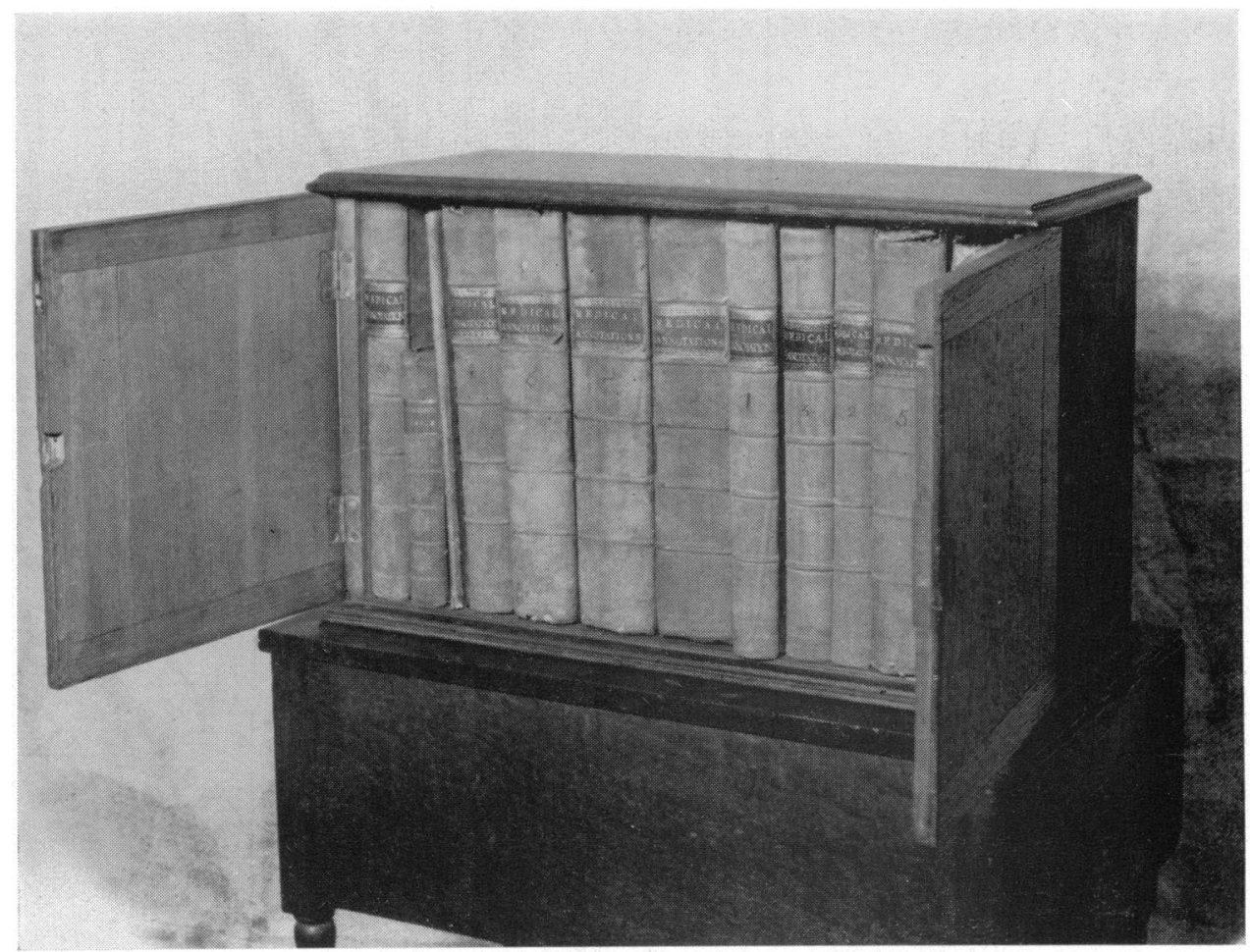

Figure 2

Pringle's manuscript volumes of Medical and Physical Observations. (Photograph by courtesy of the Royal College of Physicians, Edinburgh.) (see p. 272) 


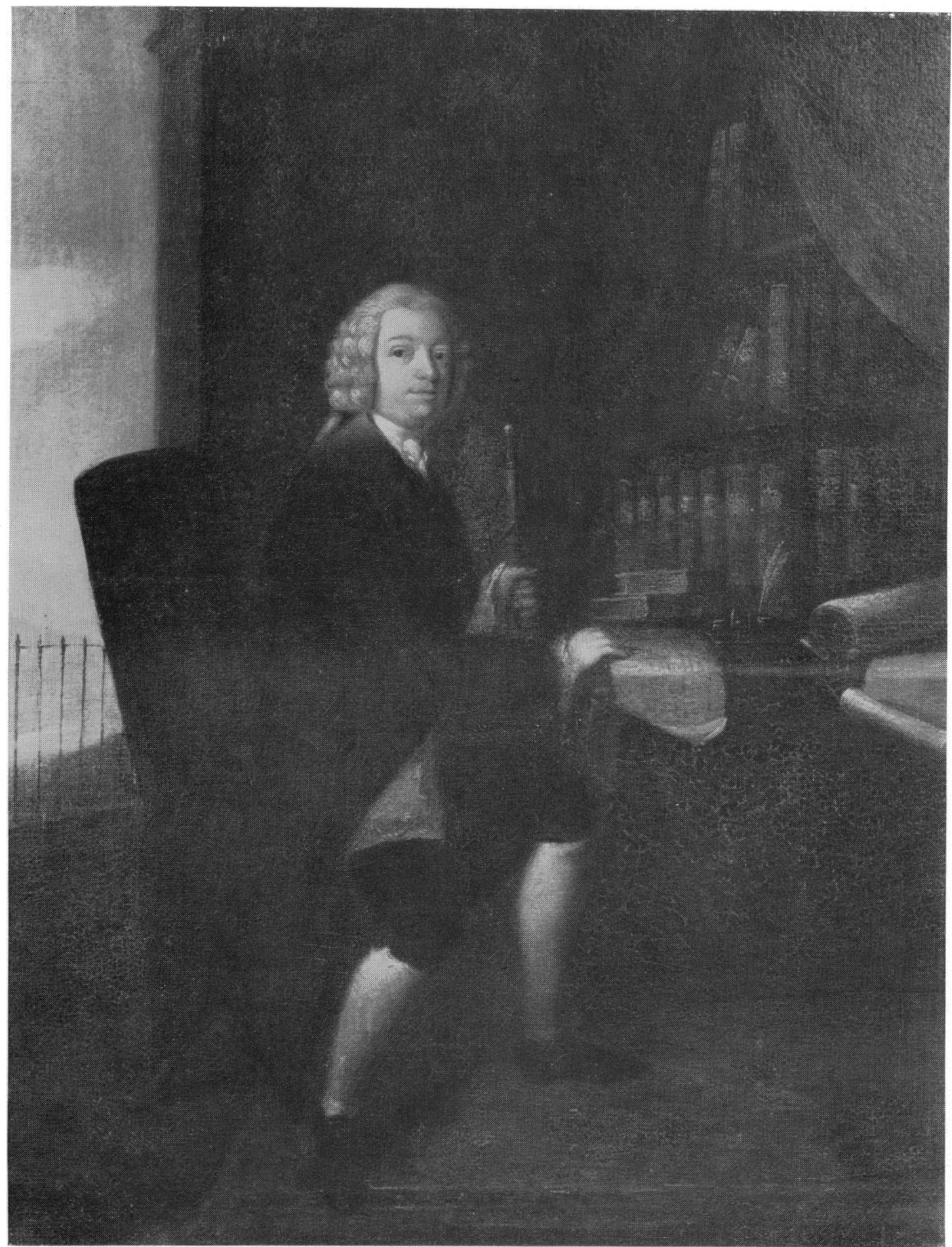

Figure 3

Oil painting of Sir John Pringle, by an unknown artist (17 inches by $13 \frac{1}{2}$ inches).

(Photograph by courtesy of the Wellcome Trustees.) (see p. 273) 


\section{Sir John Pringle}

febrile illness Pringle was advised by his friend against the bark, but subsequently another physician prescribed it, and Pringle's health was restored.

Following a two-year stay in Leyden, Pringle gained his medical degree with a dissertation entitled De Marcore Senili. ${ }^{6}$ In it are described the pathological changes which accompany ageing in the blood vessels and other structures, and their clinical significance is discussed.

After studying briefly at Paris, Pringle settled in Edinburgh as a practising physician. Nevertheless, a few years later, in 1734, he received the singular appointment of 'Professor of Pneumatical and Ethical Philosophy' at Edinburgh University.

According to Pettigrew, 'he zealously performed the duties of his office', and certainly seems to have been an able teacher of moral philosophy, though Bower ${ }^{8}$ criticised his tendency to deliver sermons; but Alexander Carlyle, who was one of his students, declared that Pringle's elegant Latin address, delivered each week, was the best part of the course. ${ }^{9}$ The Professor's lectures on the immateriality and immortality of the soul were also well received. He strongly recommended to his students the works of Lord Bacon whom he spoke of as 'the founder of experimental philosophy' and whose writings-especially Novum Organum - were to inspire much of Pringle's own scientific work.

Pringle successfully continued to practise medicine and profess moral philosophy in Edinburgh until 1742 when he was appointed physician to the British Army by its commander, Lord Stair. Despite Pringle's prolonged absence from Edinburgh he was allowed to retain his Chair, and deputies were appointed to teach in his place. Three years later he was promoted to Physician-General of the Army and he at last resigned from the University.

Some of Pringle's most important work was carried out during his six years of active service both in Flanders and at home. His reorganization of military medicine was far-reaching, but apart from the strictly medical work, which will require further attention, it was apparently due to his efforts that military hospitals came to be recognized as neutral territory and could safely be established near the battlefield, thus foreshadowing the Geneva Convention by 120 years. As a further example of his concern for the general welfare of the troops, it was at his request, too, that foot soldiers were for the first time provided with blankets.

In 1750-two years after his return to civilian life-there appeared the first published work based on Pringle's military observations. In London, where he now had a fashionable medical practice, there was a serious outbreak of jail fever which resulted in the death of the Lord Mayor, judges and others. Pringle was stimulated to publish a 52 page letter to Richard Mead on The Hospital and Jayl-Fevers. ${ }^{10}$ In this monograph Pringle was the first to assert that the two diseases were the same (typhus). The evidence he presented was obtained in 1746 following the battle of Culloden. Some English soldiers who had previously deserted to the French side in Flanders were captured while travelling to join the Jacobite rebels. During their imprisonment the deserters acquired jail fever which they then transmitted to the English troops. Hospital outbreaks followed, and the disease was at all times indistinguishable from hospital fever. Pringle's observations led him to suggest to Dr. Mead that the spread of jail fever could be prevented by enforcing 'the following regulations:-First, to 


\section{Sydney Selwyn}

allow no prisoner, upon enlargement, to carry out his cloaths; which should be burnt, and supplied by others, at the publick expense; secondly, to order, that the cloaths of malefactors, after execution, should be also burnt; but above all, that before prisoners are brought into the court, they should be cleaned and put in cloaths to be kept for that purpose, and washed from time to time.' Despite our modern knowledge of the arthropod vector we can hardly improve upon these general preventive measures.

1752 was an auspicious year for Pringle. It was then that he married the second daughter of William Oliver, the Bath physician whose memory is still celebrated with the 'Bath-Oliver' biscuit. In the same year Pringle at last published, in their entirety, his Observations on the Diseases of the Army. ${ }^{11}$ His book is of the greatest importance for it establishes Pringle as the father of modern military medicine; at the same time it contains the first scientific account of the epidemiology, pathogenesis and prevention of hospital cross-infection; moreover, the first description of antiseptics is contained in an appendix. The work went through eight English editions and was widely translated abroad-as were most of Pringle's other writings; no significant changes, however, were made after the fourth edition in 1764. In his preface, Pringle declares, 'Among the chief causes of sickness and death in an army, the Reader will little expect that I should rank, what is intended for its health and preservation, the Hospitals themselves; and that on account of the bad air, and other inconveniences attending them.'

Pringle's constant aim 'was that of preventing infection, the common and fatal consequence of a large and crouded hospital.' His views on infection were remarkably advanced at a time when the vague concepts of 'Epidemick Constitution' and 'Miasma' were generally accepted. However, a major criticism by Dorothea Singer ${ }^{3}$ was that Pringle 'seems never to have considered the hypothesis of living contagion'. Yet in the fourth edition of Pringle's book we read:

In camp, the contagion (of dysentery) passes from one, who is ill, to his companions in the same tent; and from thence perhaps to the next. The foul straw becomes very infectious ... But of what nature is this infection? In the former editions of this work, I considered the spreading of the distemper as owing to putrid exhalations from the humours of those who first fall ill of it; and that when this miasma is received into the blood, I conceived it to act upon the whole mass as a ferment, disposing it to putrefaction ... But having since perused the curious dissertation, published by Linnaeus, in favour of Kircher's system of contagion by animalcula, it seems reasonable to suspend all hypotheses, till that matter is further inquired into. ${ }^{12}$

He then gives an extensive quotation to support the hypotheses. As for the itch (scabies), Pringle writes,

It . . . seems best accounted for by Leeuwenhoeck, from certain small insects he discovered in the pustules by the microscope. So that the frequency of the itch in the army is not to be ascribed to the change of air or diet that soldiers are exposed to upon expeditions, but to the infection propagated by a few .... (and) of all places the hospitals are most liable to the contagion, as receiving all sorts of patients. ${ }^{18}$

Sulphur ointment is recommended in this condition, though 'the animalcula may sometimes lie too deep, to be thoroughly destroyed by an external application only.' Pringle was indeed one of the first to appreciate the wider medical implications of the early microscopists' findings. He had advanced views, too, on the part played 


\section{Sir John Pringle}

by factors which lower the resistance of the host, thus: 'septic particles, passing into the blood, become more active and fatal if the infected person catches cold, ${ }^{14}$ [but such factors] only dispose men to sickness and do not necessarily bring it on. It is incumbent on those who have the command, to make such provision, as shall better enable the soldier to encounter those hardships so incident to a military life. ${ }^{15}$

As a result of his epidemiological observations, Pringle was able to offer sound advice on the prevention of cross-infection in the hospital and camp. He denounced poor ventilation, overcrowding and every insanitary practice, but admitted 'what makes it hard to remedy the evil, is the difficulty of convincing either the nurses or the sick themselves of the necessity [for reform].' Most workers in this field continue to experience the same difficulty. However, Pringle was able to show in his hospitals that 'by' dispersion of the sick, and the preservation of a pure air in the wards ... any contagion might be moderated, if not prevented.'16

Pringle's campaign for improved hospital conditions was extended to the Royal Navy by another Edinburgh physician, James Lind, ${ }^{17}$ while Richard Brocklesby, ${ }^{18}$ who succeeded Pringle as Physician-General, strove to implement Pringle's reforms throughout the Army. There was, however, a considerable delay before civilian hospitals received similar attention, and once again the impetus came from Edinburgh, in the work of Sir James Simpson.19

After Pringle has considered in his Observations the hygienic measures against hospital sepsis, he then deals with more specific methods to combat infection. These involve the application of 'antiseptics' - a term which Pringle was the first to use. Thus 'faeces are rendered less, if at all infectious, by means of a strong acid combined with the parts that are really septic . . . especially in the dysentery, where the faeces . . . are highly corrupted and contagious.'

He even considered the systemic use of such substances, remarking 'were putrefaction the only change made in the body by contagion, it would be easy to cure such fevers, at any period, by the use of acids, or other antiseptics. ${ }^{20}$ Almost two centuries were to elapse before this vision became a reality.

To reinforce his discussion of antisepsis, Pringle included as an Appendix his remarkable' series of papers on Experiments upon Septic and Antiseptic Substances. These had been communicated to the Royal Society in the years 1750 to 1752, and they earned for Pringle the coveted Copley Gold Medal. The first three papers had originally been published in the Philosophical Transactions, and had also appeared in the Gentleman's Magazine.*

Pringle states in the preface to his Observations,

Two things induced me to prosecute this subject; the great number of putrid cases that were under my care in the hospitals abroad; and the authority of Lord Bacon, who offers good reasons for considering the knowledge of what brings on, and retards putrefaction, as most likely to account for some of the more obstruse operations of nature. [He concludes] ... however imperfect these sheets may be, I hope they may serve as a foundation for others to build upon; who, by making improvements on this subject, will concur with me, in attempting to draw from the calamities of war some benefit to mankind.

* Phil. Trans., 1750, 46, 480-8, 525-34, 550-8. Gentleman's Magazine, 1751, 21, 556-8, 607-9; 1752, 22, 33. 


\section{Sydney Selwyn}

The thread that joins together Pringle's somewhat diffuse writings on antisepsis is the concept that disease and putrefaction are the result of contagious ferments which can be inhibited by antiseptic substances-particularly acids and distilled spirits. The ingenious experiments which Pringle describes provide a quantitative basis for his system. Its further development to include the concept of animate contagion takes place in the later edition of his Observations, as already noted.

Another serious criticism levelled by Dorothea Singer ${ }^{3}$ against Pringle was in relation to his work on antiseptics. Mrs. Singer held that he failed to appreciate the close relationship which exists between fermentation and putrefaction, but that instead he regarded fermentation as beneficial and putrefaction as harmful. The charge is surprising, for Pringle was very explicit in this connection. Several experiments described in the third paper of the Appendix to his Observations ${ }^{11}$ are based on the concept of 'a putrid fermentation, analogous to what is found in vegetables; and this having so near a connexion with contagion'. Moreover, in a footnote he writes 'of the disposition of all putrid animal substances to promote both animal putrefaction, and a vinous fermentation in vegetables; as will appear by the sequel of these experiments'. On the other hand, putrefaction was not necessarily harmful 'For setting aside the offensive idea commonly annexed to the word, we must acknowledge putrefaction to be one of the instruments of nature, by which many great and salutary changes are brought about'.

Despite Pringle's fundamental work on antiseptics he is not mentioned by Thomson in his absorbing account of the history of the subject, ${ }^{21}$ whilst in the earlier review by Guthrie, ${ }^{22}$ mention is made, in passing, that Pringle coined the term 'antiseptic.'

The clinical relevance of Pringle's work was demonstrated seventy years later by the heroic experiments of Ollivier ${ }^{23}$ who fully acknowledged his debt to Pringle. However, more complete fulfilment came over a century later, following the work of another Edinburgh professor. It is doubtful, though, whether Lister ${ }^{24}$ was aware of, or at all influenced by his predecessor's early labours in this field. Moreover, the relationship between fermentation and putrefaction which greatly interested Pringle also became a preoccupation of Lister in his later work. ${ }^{22}$

Pringle's lesser writings consist of a number of papers on extremely varied topics. Most of these communications were published in the Philosophical Transactions of the Royal Society, and they include an account of the epidemiology of jail fever at Newgate, a study of Fragility, Flexibility, and Dissolution of the Bones, descriptions of earthquakes in Scotland and abroad, a discussion of cures for the stone, and a detailed account of a contemporary meteor. ${ }^{25}$ In addition he contributed to the Edinburgh Medical Essays an early paper on the specific value of antimony in dysentery. ${ }^{26}$ The paper on jail fever was deemed of such importance by the Rev. Stephen Hales that he had it published in the Gentleman's Magazine* to secure its widest dissemination. Parts of the Observations were also reprinted in that journal.

Apart from his own papers, he communicated to the Royal Society on behalf of others an astonishing variety of letters most of which were reviewed by Mrs. Singer. ${ }^{3}$ They deal with subjects as diverse as archaeology, music, surgery, mathematics, geology, the uses of electricity in medical practice, the virtues of mineral waters, the

\footnotetext{
* Gentleman's Magazine, 1753, 23, 21-2, 71-4, 172-3.
} 


\section{Sir John Pringle}

domestication of foreign plants, the reviviscence of snails, and 'the extraordinary effect of lightning'.

Pringle seems also to have written in 1760 the first biography of General Wolfe. This small work which is in the British Museum is not mentioned by any writer on Pringle. It has the grandiose title The Life of General Wolfe, the Conqueror of Canada: or, the Elogium of that renowned Hero, Attempted according to the rules of Eloquence. With a monumental inscription. Latin and English, To perpetuate his Memory, By $J * * * P^{* * * * * *}, A . M$. The title, style and anonymity are out of keeping with what we know of Pringle, but Webster ${ }^{27}$ presents convincing documentary evidence for his attribution. Pringle himself excuses his extravagant eulogy on the grounds of novelty 'and the excellence of the object it celebrates'. Pringle must have known Wolfe well, having served with him on several occasions.

In 1772 Pringle was elected President of the Royal Society. By this time he was Physician to the Queen, and a Baronetcy had been conferred upon him. Shortly afterwards he was appointed Physician to the King, and he received numerous other honours-both at home and abroad. During his six years as President of the Royal Society, Pringle established the custom of introducing the annual Copley Medallist with a weighty discourse. Each of these allowed full scope to Pringle's universal mind. The Discourses were originally published in the Philosophical Transactions, but were later reissued by Kippis. ${ }^{1}$ They deal with the preservation of the health of mariners, the properties of the torpedo and of the different kinds of air, the development of the reflecting telescope, the gravitational attraction of mountains, and the philosophical implications of gunnery.

The last work by Pringle to be published ${ }^{28}$ was written in 1775 , but did not appear until 1784 - two years after the author's death. It is a short paper on the clinical features and epidemiology of influenza, in reply to John Fothergill's Sketch of the Epidemic Disease . . . in London. ${ }^{29}$ Pringle demolishes the lingering concept of 'epidemical constitution' of the air, stating 'that the sensible qualities of the air had most probably no share in producing this Epidemic'. He supports this view with sound concise arguments based on epidemiological observations. He concludes 'such epidemics (of which there have been four in my remembrance) do not depend on any principles we are acquainted with, but upon some others, to be investigated'. This brief communication was the subject of controversy for many years, as can be seen for example in the paper on influenza written by Moodie in $1804 .^{30}$

In Pringle's scientific and medical writings there is no place for the fanciful hypotheses and idle speculations which were so popular at the time. His work is the result of careful observation and sound reasoning, and it is permeated by a genuine humility. If, in his medical writings, thorough clinical and morbid anatomical descriptions do not invariably lead to the 'correct' interpretation, Pringle, nevertheless, is always painfully aware of the imperfect state of medical science in his day. His deductions are therefore cautious, and are usually accompanied by a plea for further research.

Pringle's artistic and general accomplishments were also of a high order. He was a gifted musician, the violoncello being his chosen instrument. His knowledge of ancient and modern languages was considerable, and he conducted a voluminous 


\section{Sydney Selwyn}

correspondence with eminent men throughout Europe-but unfortunately destroyed most of his letters before his death. He was, moreover, a distinguished antiquary and a discerning amateur of paintings and prints. The study of divinity was a particular hobby of Pringle's, and some of his theological correspondence with Michaelis was published in 1773.* Pringle's religious beliefs were informed by the same rational processes as his scientific work; and it was apparently on account of his Unitarian views that James Boswell, who described Pringle as 'mine own friend and my father's friend', ${ }^{31}$ was unable to arrange for him to meet Samuel Johnson. ${ }^{32}$ Pringle's only failings were, according to his friend, Kippis, a fondness for the critical writings of Voltaire, and an inadequate appreciation of English poetry, including the works of Shakespeare.

As physician, Pringle was in great demand, drawing his patients from far and near. Thus we read in a letter written by Andrew Dalzel, 'David Hume's health is declining. $\mathrm{He}$ is gone to London to consult Sir John Pringle'. ${ }^{33}$ This orthodox medical consultation between two acknowledged moral philosophers must be unique.

Pringle's resignation from the Presidency of the Royal Society in 1778 may partly have been the result of failing health-he was then aged 71-but undoubtedly he was distressed by a strange and bitter controversy which divided the Society. Sides were taken on the question-to quote Kippis-'whether pointed or blunted electrical conductors are the most efficacious in preserving buildings from the pernicious effects of lightning'. Pringle himself seems to have favoured the pointed, projecting variety, for he demonstrates the value of this type in the allegorical plate which embellishes page 1 of the seventh edition of his Observations. ${ }^{15}$

Two years later, he disposed of his library, sold his London house and retired to Edinburgh. In the rather partial view of Allerdyce, ${ }^{34}$ 'After living a number of years in England and being in high favour at Court, he retired in disgust from practice, and returned to his native country'. However, most of Pringle's old friends were dead, and, Robert Chambers adds feelingly, 'he also suffered considerably from the keen winds to which Edinburgh is so remarkably exposed'. ${ }^{35}$ After five months, he returned to London, but, before leaving Scotland, he presented to the Royal College of Physicians of Edinburgh his Medical and Physical Observations in ten folio volumes of manuscripts. As can be seen from the inscription on its case (fig. 1), the gift was made with the strange proviso that it must never be published or lent by the College. Dorothea Singer ${ }^{3}$ had not examined this work but believed that it was merely a collection of case records. In fact, it provides a complete account of medical practice in the mid-eighteenth century, and is illuminated by detailed observations from a wide variety of cases. It would indeed be tragic if a whim of the author were to consign one of his greatest works to oblivion.

Sir John Pringle died on 18 January 1782, four months after his return to London. Few memorials remain. His birthplace at Stichill was bought by an ironmaster, and demolished in 1863 . The beautiful estate was subsequently laid waste, and it is now used by a pig farmer. Pringle's grave at St. James's Church, Piccadilly, was destroyed

* (Cited by Kippis) Johannis Davidis Michaelis, Prof. Ordin. Philos. et Soc. Reg. Scient. Goettingensis Collegae; Epistolae, de LXX Hebdomadibus Danielis, ad D. Johannem Pringle, Baronettum: Primò privatim missae, nunc vero utriusque consensu publice editae, 8vo, London, 1773. 


\section{Sir John Pringle}

by a bomb during World War II. We are left with two portraits and an elegant monument by Nollekens in Westminster Abbey ${ }^{36}$ (It is perhaps ironical that the monument is in Poets' Corner.) One of the portraits was painted by Reynolds in 1774 and is in the possession of the Royal Society. An engraving of it by Mote is reproduced by Pettigrew. ${ }^{7}$ Unfortunately, the painting is not one of Reynolds' most sympathetic works. The second oil-painting is in the collection of the Wellcome Historical Medical Museum. Neither the date nor the artist is known, but the portrait has great dignity and contains interesting details (fig. 3).

In Payne's words 'few physicians have rendered more definite and brilliant services to science and humanity', ${ }^{32}$ yet Pringle has been neglected or underrated for almost two centuries. The current edition of Scotland's only biographical dictionary does not mention him, nor does the largest British encyclopaedia. A full reappraisal of the life and works of one of the most interesting figures in medical history is long overdue.

ACKNOWLEDGEMENT

I am grateful to Mr. J. W. Barber-Lomax of the Wellcome Historical Medical Museum for drawing my attention to the portrait of Pringle reproduced in Fig. 3.

\section{REFERENCES}

1. Six Discourses, delivered by Sir John Pringle, Bart. when President of the Royal Society: On occasion of Six Annual Assignments of Sir Godfrey Copley's Medal. To which is prefixed a life of the Author, by Andrew Kippis, D.D., F.R.S. and S.A., London, W. Strahan and T. Cadell, 1783.

2. Hutchinson, B., Biographia Medica: or Historical and Critical Memoirs of the Lives and Writings of the most Eminent Medical Characters . . . in Two Volumes. London, J. Johnson, 1799, Vol. II, pp. 299-324.

3. Singer, Dorothea Waley, 'Sir John Pringle and his circle', Ann. Sci., 1949-50, 6, $127-80,229-61$.

4. KING, L. S., The Medical World of the Eighteenth Century, Chicago, University of Chicago Press, 1958, pp. 133-8.

5. Hamiton, D., 'Sir John Pringle', J. roy. Army Med. Corps., 1964, 110, 138-47.

6. Dissertatio Medica Inauguralis De Marcore Senili quam, Annuente Deo Ter Opt. Max. ex Auctoritate Magnifici Rectoris, D. Hermanni Boerhaave . . Eruditorum Examini Submittit Joannes Pringle Scoto-Britannus ad diem 20. Julii 1730. hora locoque solitis, Lugduna Batavorum, apud Jon. Arnold. Langerak, 1730.

7. Pettigrew, T. J., Medical Portrait Gallery, Biographical Memoirs of the Most Celebrated Physicians, Surgeons etc. who have contributed to the Advancement of Medical Science, London \& Paris, Fisher Son \& Co., 1839, Vol. II. (14th memoir).

8. BOWER, A., The History of the University of Edinburgh, Edinburgh, 1817, Vol. II, pp. 286-96.

9. The Autobiography of the Rev. Dr. Alexander Carlyle, Minister of Inveresk, Edinburgh \& London, William Blackwood \& Sons, 1860, p. 48.

10. PrIngle, J., Observations on the Nature and Cure of Hospital and Jayl-Fevers. In a Letter to Doctor Mead, London, A. Millar and D. Wilson, 1750, p. 50.

11. Observations on the Diseases of the Army, in Camp and Garrison. In Three Parts. With an Appendix containing some Papers of Experiments read at several Meetings of the Royal Society, London, A. Millar, D. Wilson, \& T. Payne, 1752.

12. Ibid., 4th ed., 1764, pp. 263-7.

13. Ibid., pp. 350-3.

14. Ibid., p. 341 . 


\section{Sydney Selwyn}

15. Ibid., 7th ed., 1774, p. 93.

16. Ibid., 4th ed., pp. 109, 45.

17. LIND, J., An Essay on the most Effectual Means of Preserving the Health of Seamen ..., London, A. Millar, 1757.

18. Brocklesby, R., Oeconomical and Medical Observations in two Parts. From the Year 1758 to the Year 1763, inclusive. Tending to the Improvement of Military Hospitals, and to the Cure of Camp Diseases, Incident to Soldiers, London, T. Becket \& P. A. Hondt, 1764.

19. Selwyn, S., 'Sir James Simpson and hospital cross-infection', Med. Hist., 1965, 9, 241-248.

20. Pringle, J., Observations on the Diseases of the Army ... ., 4th ed., pp. 346-8.

21. Thomson, W. A. R., 'From antisepsis to antibiosis', in Chemistry in the Service of Medicine, ed. F. N. L. Poynter, London, Pitman, 1963, pp. 160-77.

22. GutHRIE, D., From Witchcraft to Antisepsis: A Study in Antithesis, Lawrence, University of Kansas Press, 1955, part II.

23. OllivieR, A. F., Traité expérimental du typhus traumatique, gangrene on pourriture des hôpitaux: contenant des observations nouvelles sur diverse gangrènes, épidémies, contagions: sur les antiseptiques, les désinfectans, etc: et sur de nouveaux moyens hygiéniques, applicable aux hôpitaux, Paris, Mme Seignot, 1822.

24. LISTER, J., 'On a new method of treating compound fracture, abscess, etc. with observations on the conditions of suppuration', Lancet, 1867, i, 326-9, 357-9, 387-9, 507-9, ii, 95-6.

25. Pringle, J., Phil. Trans., 1753, 48, 42-55, 297-301; 1756, 49, 509-11, 546-7, 550-1; $1757,50,205-9,219,221 ; 1759,51,218-74$.

26. 'Vitrium antimonii ceratum, a specific medicine in the dysentery', Medical Essays and Observations revised and published by a Society in Edinburgh, 1742, 5, part i, 194-219.

27. Webster, J. C., 'The first published life of James Wolfe', Canad. hist. Rev., 1930, 11, 328-32.

28. PrIngle, J., 'Observations on the influenza', Medical Observations and Inquiries by a Society of Physicians in London, 1784, 6, 348-9.

29. FothERGILL, J., 'Sketch of the epidemic disease which appeared in London towards the end of the year 1775', Ibid., 340-7.

30. Moodie, J., 'On the epidemic catarrh commonly termed the influenza', Medical and Physical Journal, 1804, 11, 488-92.

31. Boswell's Life of Johnson, London, Macmillan, 1898, p. 377.

32. PAYNe, J. F., in Dictionary of National Biography, London, Smith Elder, 1896, vol. 16, pp. 386-8.

33. Dalzel, A., History of the University of Edinburgh with a Memoir of the Author, Edinburgh, Edmonston and Douglas, 1862, Vol. I, p. 22.

34. AllerdyCE, A., Scotland and Scotsmen in the Eighteenth Century, Edinburgh and London, 1888, Vol. I. p. 230.

35. Chambers, R., A Biographical Dictionary of Eminent Scotsmen, Glasgow, Blackie, 1835 vol 4, p. 122.

36. The History of the Abbey Church of St. Peter's Westminster, Its Antiquities and Monuments, London, R. Ackermann, 1812, vol, II, p. 67. 


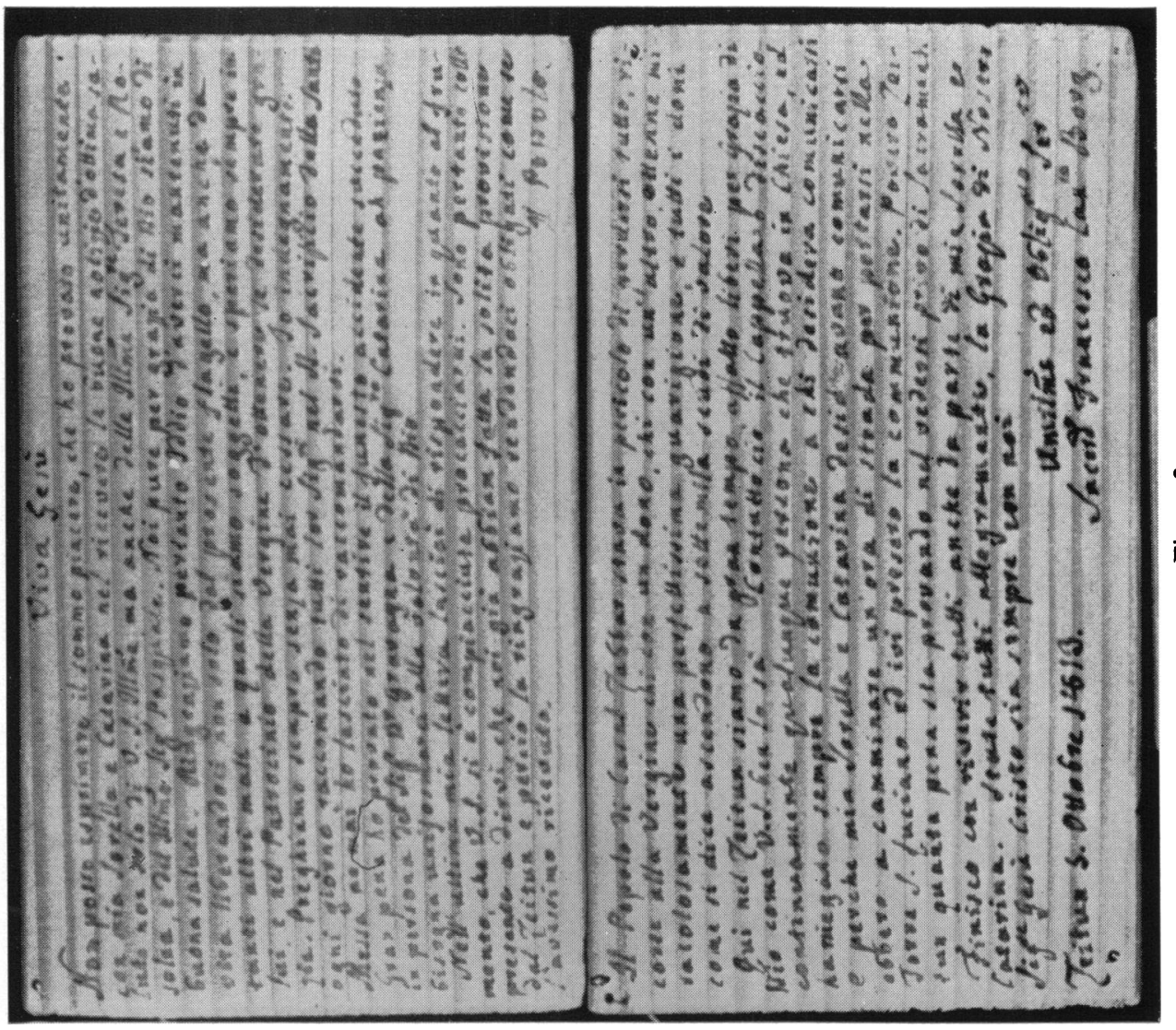

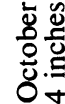

ำ

这客

政品

N.E医

ธี่

垔券方

$8 . \frac{2}{8}$

हैํํㅇ

D

.

$\sim$ 焉要

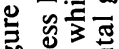

语

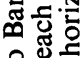

on

实

L

这苍

幽实

ฆ气

톨.

包可

$\frac{m}{\infty}$
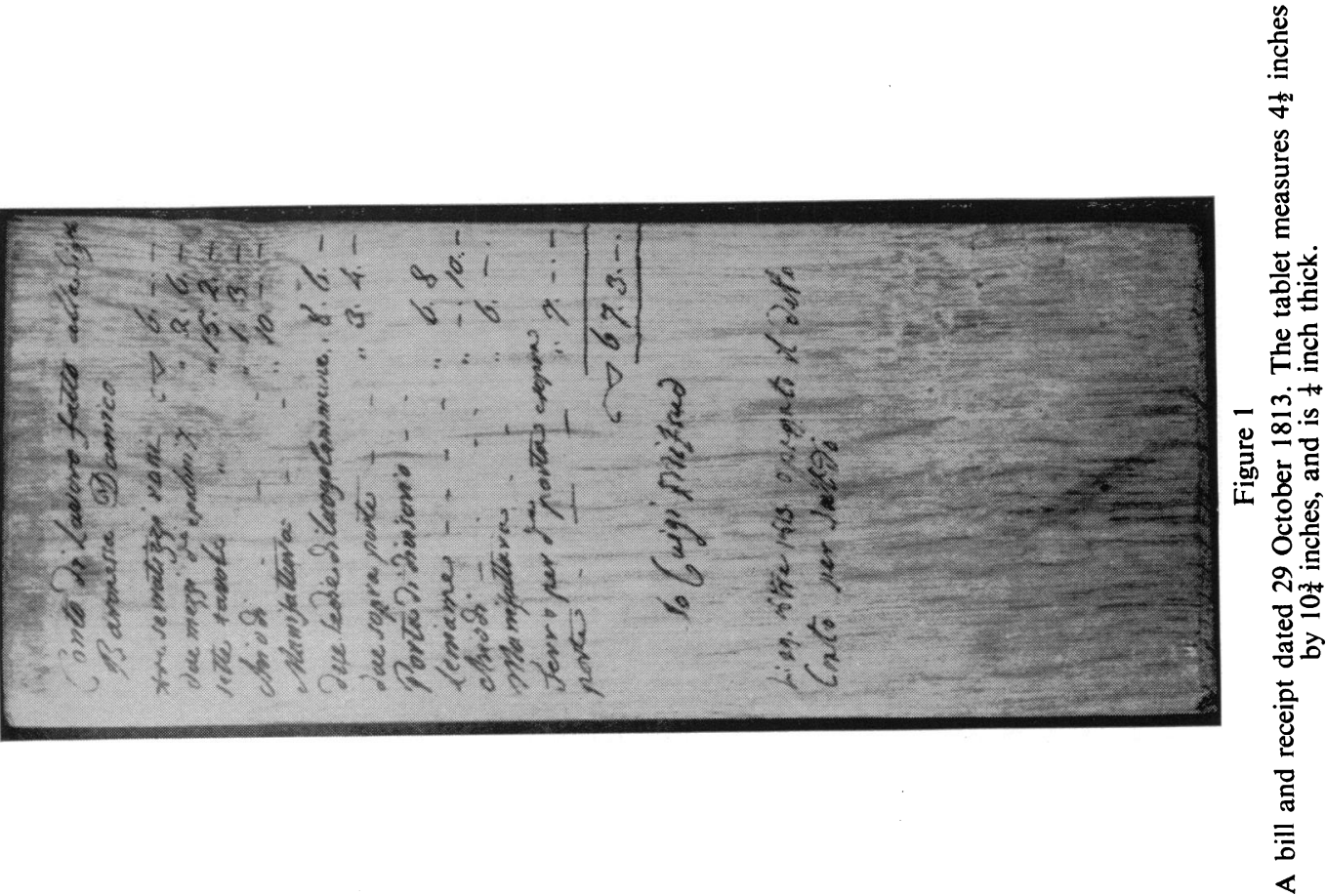